\title{
PLOT SIZE, NUMBER OF TREATMENTS AND REPLICATES AND EXPERIMENTAL PRECISION IN BUCKWHEAT ${ }^{1}$
}

\author{
ALBERTO CARGNELUTTI FILHO ${ }^{2 *}$, ISMAEL MARIO MÁRCIO NEU ${ }^{3}$, JÉSSICA MARONEZ DE SOUZA ${ }^{3}$, RAFAEL \\ VIEIRA PEZZINI ${ }^{3}$, GABRIEL ELIAS DUMKE ${ }^{4}$, FELIPE MANFIO SOMAVILLA ${ }^{4}$
}

\begin{abstract}
The objective of this work was to determine the optimal plot size to evaluate the fresh weight in buckwheat (Fagopyrum esculentum Moench) of the IPR91-Baili and IPR92-Altar cultivars, in scenarios formed by combinations of numbers of treatments, numbers of replicates, and levels of experimental precision. Sixteen uniformity trials (blank experiments) were carried out, eight with cultivar IPR91-Baili and eight with cultivar IPR92-Altar. The trials were performed in eight sowing dates. The fresh weight was evaluated in 576 basic experimental units (BEU) of $1 \mathrm{~m} \times 1 \mathrm{~m}$ (36 BEU per trial). The soil heterogeneity index of Smith (1938) was estimated. The plot size was determined by the method of Hatheway (1961) in scenarios formed by combinations of i treatments $(\mathrm{i}=5,10,15$, and 20), $r$ replicates $(\mathrm{r}=3,4,5,6,7$, and 8$)$, and d precision levels $(\mathrm{d}=10 \%, 11 \%, 12 \%, 13 \%, 14 \%, 15 \%, 16 \%, 17 \%, 18 \%, 19 \%$, and 20\%). To evaluate the fresh weight in buckwheat of the IPR91-Baili and IPR92-Altar cultivars, in experiments under completely randomized and randomized block designs, with 5 to 20 treatments and eight replicates, plots of $8 \mathrm{~m}^{2}$ of useful area are sufficient to identify significant differences between treatments, at $5 \%$ probability level, of $15 \%$ of the overall mean of the experiment.
\end{abstract}

Keywords: Fagopyrum esculentum Moench. Soil cover crop. Uniformity trial. Experimental design.

\section{TAMANHO DE PARCELA, NÚMEROS DE TRATAMENTOS E DE REPETIÇÕES E A PRECISÃO EXPERIMENTAL EM TRIGO MOURISCO}

RESUMO - O objetivo deste trabalho foi determinar o tamanho ótimo de parcela para avaliar a massa de matéria fresca de trigo mourisco (Fagopyrum esculentum Moench) das cultivares IPR91-Baili e IPR92-Altar, em cenários formados por combinações de números de tratamentos, números de repetições e níveis de precisão experimental. Foram conduzidos 16 ensaios de uniformidade (experimentos em branco), sendo oito com a cultivar IPR91-Baili e oito com a cultivar IPR92-Altar. Os ensaios foram realizados em oito épocas de semeadura. Foi avaliada a massa de matéria fresca em 576 unidades experimentais básicas (UEB) de $1 \mathrm{~m} \times 1 \mathrm{~m}$ (36 UEB por ensaio). Foi estimado o índice de heterogeneidade do solo de Smith (1938). Foi determinado o tamanho de parcela por meio do método de Hatheway (1961) em cenários formados pelas combinações de i tratamentos $(i=5,10,15$ e 20), $r$ repetições $(r=3,4,5,6,7$ e 8) e d níveis de precisão $(\mathrm{d}=10 \%, 11 \%, 12 \%, 13 \%, 14 \%, 15 \%, 16 \%, 17 \%, 18 \%, 19 \%$ e 20\%). Para avaliar a massa de matéria fresca de trigo mourisco das cultivares IPR91-Baili e IPR92-Altar, nos delineamentos inteiramente casualizado e blocos completos ao acaso, com 5 a 20 tratamentos e oito repetições, parcelas de $8 \mathrm{~m}^{2}$ de área útil são suficientes para identificar diferenças significativas entre tratamentos, a $5 \%$ de probabilidade, de $15 \%$ da média geral do experimento.

Palavras-chave: Fagopyrum esculentum Moench. Cultura de cobertura de solo. Ensaio de uniformidade. Dimensionamento experimental.

\footnotetext{
${ }^{*}$ Corresponding author

${ }^{1}$ Received for publication in $03 / 25 / 2020$; accepted in $05 / 14 / 2020$.

Paper of the Experimentation Research Group.

${ }^{2}$ Department of Crop Science, Universidade Federal de Santa Maria, Santa Maria, RS, Brazil; alberto.cargnelutti.filho@gmail.com ORCID: 0000-0002-8608-9960.

${ }^{3}$ Postgraduate Program in Agronomy, Universidade Federal de Santa Maria, Santa Maria, RS, Brazil; ismaelmmneu@hotmail.com ORCID: 0000-0002-9186-2532, jessica_maronez@hotmail.com - ORCID: 0000-0002-0856-9475, rvpezzini@hotmail.com - ORCID: 0000 $-0003-4134-2499$.

${ }^{4}$ Graduate in Agronomy, Universidade Federal de Santa Maria, Santa Maria, RS, Brazil; gabrieleliasdumke@gmail.com - ORCID: 00000002-0301-7137, felipe-somavilla@hotmail.com - ORCID: 0000-0002-1648-0219.
} 


\section{INTRODUCTION}

Buckwheat (Fagopyrum esculentum Moench) is an annual plant of the Polygonaceae family (ACCAME; ORTEGA, 2019). It has rapid growth, short cycle, tolerates acidity and develops in low-fertility soils (GONÇALVES et al., 2016). It can be used for human and animal consumption, as a medicinal plant and soil cover plant (ZIECH et al., 2015; GONÇALVES et al., 2016; GÖRGEN et al., 2016; PEREIRA et al., 2017; SKORA NETO; CAMPOS, 2017; ACCAME; ORTEGA, 2019; MIKHAILOVICH, 2019; YILMAZ; AYHAN; MERIÇ, 2020).

Considering the importance of this crop, it is essential that inferences regarding treatments be accurate in field experiments. For this, it is necessary to define plot size and number of replicates, which can be performed through uniformity trials. In these trials the experimental area can be divided into basic experimental units (BEU) (STORCK et al., 2016). The data of these $\mathrm{BEU}$ can be used to calculate the coefficient of variation (CV) between the BEU and the soil heterogeneity index (b) of Smith (1938). The CV and b index estimates can be used in the methodology of Hatheway (1961) to calculate the optimal plot size according to the experimental design, number of treatments, number of replicates and experimental precision. With this methodological approach, after establishing the experimental design and the number of treatments, the researcher can choose the best combination of plot size, number of replicates and level of experimental precision.

Studies with buckwheat together with other soil cover species have been conducted in the randomized complete block design and with different plot sizes and number of replicates, such as: $25 \mathrm{~m}^{2}$ and three replicates (ZIECH et al., 2015); $20 \mathrm{~m}^{2}$ and three replicates (GÖRGEN et al., 2016); $4 \mathrm{~m}^{2}$ and six replicates (PEREIRA et al., 2017); and $24 \mathrm{~m}^{2}$ and four replicates (SKORA NETO; CAMPOS, 2017). These studies pointed out promising aspects of buckwheat and other soil cover species and no reference was mentioned regarding the definition of plot size and number of replicates for fresh weight evaluation. Also, no approach to the coefficient of variation of fresh weight was mentioned.

Applying the methodologies of Smith (1938) and Hatheway (1961) in a set of uniformity trials conducted in different sowing periods and with different cultivars makes it possible to generate useful information to be used as a reference in the planning of experiments with buckwheat crop, aiming at higher experimental precision. These methodologies have been used in beans (MAYOR -DURÁN; BLAIR; MUÑOZ, 2012), sunflower (SOUSA et al., 2015; SOUSA; SILVA; ASSIS, 2016), banana (DONATO et al., 2018), cactus pear (GUIMARÃES et al., 2019; GUIMARÃES et al., 2020) and in species with potential for soil cover, such as: velvet bean (CARGNELUTTI FILHO et al., 2014a); forage turnip (CARGNELUTTI FILHO et al., 2014b); and flax (CARGNELUTTI FILHO et al., 2018).
It is assumed that the application of these methodologies is promising for the definition of experimental planning in buckwheat crop. Thus, the objective of this study was to determine the optimal plot size to evaluate the fresh weight of buckwheat (Fagopyrum esculentum Moench) of the cultivars IPR91 -Baili and IPR92-Altar, in scenarios formed by combinations of numbers of treatments, numbers of replicates and levels of experimental precision.

\section{MATERIAL AND METHODS}

Sixteen uniformity trials were conducted with buckwheat crop in the experimental area located at $29^{\circ} 42^{\prime}$ S, 53⒋ $\mathrm{W}$ and $95 \mathrm{~m}$ altitude. According to Köppen's classification, the climate of the site is humid subtropical Cfa, with hot summers and without dry season (ALVARES et al., 2013) and the soil is Argissolo Vermelho Distrófico Arênico (Ultisol) (SANTOS et al., 2018). Physical and chemical analyses of the soil in the 0 - $20 \mathrm{~cm}$ layer revealed: $\mathrm{pH}$ water 1:1: 5.5; Ca: $4.7 \mathrm{cmol}_{\mathrm{c}} \mathrm{dm}^{-3}$; Mg: $1.9 \mathrm{cmol}_{\mathrm{c}} \mathrm{dm}^{-3}$; $\mathrm{Al}: 0.0 \mathrm{cmol}_{\mathrm{c}} \mathrm{dm}^{-3}$; $\mathrm{H}+\mathrm{Al}: 4.4 \mathrm{cmol}_{\mathrm{c}} \mathrm{dm}^{-3}$; SMP index: 6.0; organic matter: $2.3 \%$; clay content: $29.0 \%$; S: $1.5 \mathrm{mg} \mathrm{dm}^{-3}$; P (Mehlich): $32.8 \mathrm{mg} \mathrm{dm} \mathrm{dm}^{-3} ; \quad \mathrm{K}: 0.532 \mathrm{cmol}_{\mathrm{c}} \mathrm{dm}^{-3} ; \mathrm{CTC}_{\mathrm{pH} 7}$ : $11.6 \mathrm{cmol}_{\mathrm{c}} \mathrm{dm}^{-3} ; \mathrm{Cu}: 2.2 \mathrm{mg} \mathrm{dm}^{-3} ; \mathrm{Zn}: 1.01 \mathrm{mg} \mathrm{dm}^{-3}$; and B: $0.2 \mathrm{mg} \mathrm{dm}^{-3}$.

In each of the following times (12/18/2017, $01 / 03 / 2018, \quad 03 / 14 / 2018, \quad 11 / 06 / 2018, \quad 12 / 28 / 2018$, $01 / 30 / 2019$, 02/22/2019, and 03/28/2019), two uniformity trials were installed, one with the cultivar IPR91-Baili and the other with the cultivar IPR92-Altar, totaling 16 uniformity trials (eight with IPR91-Baili and eight with IPR92-Altar). In all trials, sowing was carried out in rows, spaced apart by $0.5 \mathrm{~m}$, with density of $50 \mathrm{~kg} \mathrm{ha}^{-1}$ and basal fertilization with $35 \mathrm{~kg} \mathrm{ha}^{-1}$ of $\mathrm{N}$; $135 \mathrm{~kg} \mathrm{ha}^{-1}$ of $\mathrm{P}_{2} \mathrm{O}_{5}$ and $135 \mathrm{~kg} \mathrm{ha}^{-1}$ of $\mathrm{K}_{2} \mathrm{O}$. Evaluations of fresh weight (FW) were carried out, respectively, on $02 / 15 / 2018, \quad 03 / 14 / 2018, \quad 05 / 10 / 2018, \quad 12 / 27 / 2018$, $02 / 14 / 2019,04 / 03 / 2019,04 / 15 / 2019$ and $05 / 20 / 2019$, i.e. at $59,70,57,51,48,63,52$ and 53 days after sowing, coinciding with the final flowering period and start of grain formation.

In each uniformity trial with a dimension of $8 \mathrm{~m}$ $\times 8 \mathrm{~m}\left(64 \mathrm{~m}^{2}\right)$, the central area with size of $6 \mathrm{~m} \times 6 \mathrm{~m}$ $\left(36 \mathrm{~m}^{2}\right)$ was divided into 36 basic experimental units (BEU) of $1 \mathrm{~m} \times 1 \mathrm{~m}\left(1 \mathrm{~m}^{2}\right)$, forming a matrix of six rows and six columns. In each BEU, the plants were cut close to the soil surface, and their FW was immediately weighed, in $\mathrm{g} \mathrm{m}^{-2}$, on a digital scale (accuracy: $1 \mathrm{~g}$ ). Weighing was performed immediately after cutting, in order to minimize the possible variations in plant moisture. Fresh weight samples were collected in six randomly chosen BEUs of each uniformity trial. The samples were placed in paper bags identified by BEU and dried in an oven with forced air ventilation at $65 \pm 3{ }^{\circ} \mathrm{C}$, until reaching constant weight, to determine the dry weight (in $\%$ and in $\mathrm{g} \mathrm{m}^{-2}$ ). This sampling was only performed to quantify the dry weight in each 
uniformity trial.

For each uniformity trial, the FW data of the 36 BEU were used to plan plots with adjacent $X_{R}$ BEU in the row and adjacent $\mathrm{X}_{\mathrm{C}} \mathrm{BEU}$ in the column. Plots with different sizes and/or shapes were planned as $\left(\mathrm{X}=\mathrm{X}_{\mathrm{R}} \times \mathrm{X}_{\mathrm{C}}\right)$, i.e. $(1 \times 1),(1 \times 2),(1 \times 3),(1 \times 6),(2 \times 1),(2 \times 2)$, $(2 \times 3),(2 \times 6),(3 \times 1),(3 \times 2),(3 \times 3),(3 \times 6),(6 \times 1),(6 \times 2)$ and $(6 \times 3)$. The acronyms $X_{R}, X_{C}$ and $X$, respectively, represent the number of adjacent BEU in the row, number of adjacent BEU in column, and plot size in number of BEU. For each plot size $(\mathrm{X})$, the following parameters were determined: number of plots with $\mathrm{X}$ BEU size $(n=36 / X) ; M_{(X)}$ - mean of plots with X BEU size; $\mathrm{V}_{(\mathrm{X})}$ - variance between plots with $\mathrm{X}$ BEU size; $\mathrm{CV}_{(\mathrm{X})}$ - coefficient of variation (in \%) between plots with $\mathrm{X}$ BEU size; and $\mathrm{VU}_{(\mathrm{X})}$ - variance by BEU between plots with $\mathrm{X}$ BEU size $\left[\mathrm{VU}_{(\mathrm{X})}=\mathrm{V}_{(\mathrm{X})} / \mathrm{X}^{2}\right]$.

In each of the 16 trials, the parameters V1 (estimation of variance by BEU between the plots with size of one BEU) and $b$ (estimation of the soil heterogeneity index) and the coefficient of determination $\left(\mathrm{R}^{2}\right)$ of the function $\mathrm{VU}_{(\mathrm{X})}=\mathrm{V} 1 / \mathrm{X}^{\mathrm{b}}$, of Smith (1938), were estimated. These parameters were estimated by logarithmic transformation and linearization of the function $\mathrm{VU}_{(\mathrm{X})}=\mathrm{V} 1 / \mathrm{X}^{\mathrm{b}}$ (SMITH, 1938), i.e., $\log \mathrm{VU}_{(\mathrm{X})}=$ $\log \mathrm{V} 1-\mathrm{b} \log \mathrm{X}$, whose estimation was weighted by the degrees of freedom $(\mathrm{DF}=\mathrm{n}-1)$, associated with each plot size, according to the application of Sousa, Silva and Assis (2016). The observed values of the dependent $\left[\mathrm{VU}_{(\mathrm{X})}\right]$ and independent $(\mathrm{X})$ variables and the function $\mathrm{VU}_{(\mathrm{X})}=\mathrm{V} 1 / \mathrm{X}^{\mathrm{b}} \quad(\mathrm{SMITH}, 1938)$ were represented graphically.

Experimental plans were simulated in completely randomized (CRD) and randomized complete block (RCBD) designs for the combinations of $\mathrm{i}$ treatments ( $\mathrm{i}=$ $5,10,15$ and 20), $r$ replicates $(r=3,4,5,6,7$ and 8$)$ and $\mathrm{d}$ differences between means of treatments to be detected as significant at $5 \%$ probability level, expressed as a percentage of the overall mean of the experiment, i.e., in levels of experimental precision $[\mathrm{d}=10 \%$ (higher precision), $11 \%, 12 \%, 13 \%, 14 \%, 15 \%, 16 \%, 17 \%, 18 \%$, $19 \%$ and $20 \%$ (lower precision)].

For each experimental plan, the optimal plot size (Xo), in number of BEU (approximated to the upper integer), was calculated using the expression $X o=\sqrt[b]{2\left(t_{1}+t_{2}\right)^{2} C V^{2} / r d^{2}}$ (HATHEWAY, 1961). In this expression, $b$ is the estimate of the soil heterogeneity index (in this study, for each cultivar, the mean $b$ of the eight uniformity trials was used); $t_{1}$ is the critical value of the Student's t-distribution for the significance level of the test (type I error) of $\alpha=5 \%$ (bilateral test at $5 \%$ ), with DF degrees of freedom; $t_{2}$ is the critical value of the Student's t-distribution, corresponding to 2(1-P) (bilateral test), where $\mathrm{P}$ is the probability of obtaining a significant result, i.e., the power of the test $(\mathrm{P}=0.80$, in this study), with $\mathrm{DF}$ degrees of freedom; $\mathrm{CV}$ is the estimate of the coefficient of variation between the plots with size of one BEU (in this study, for each cultivar, the mean $\mathrm{CV}$ of the eight uniformity trials was used), as a percentage; $r$ is the number of replicates; and $\mathrm{d}$ is the difference between means of treatments to be detected as significant at 5\% probability level, expressed as a percentage of the overall mean of the experiment (precision). The degrees of freedom (DF) to obtain the critical values (tabulated) of Student's t-distribution were obtained by the expressions $\mathrm{DF}=(\mathrm{i})(\mathrm{r}-1)$, for the $\mathrm{CRD}$, and $\mathrm{DF}=(\mathrm{i}-1)(\mathrm{r}-1)$, for the RCBD, where $i$ is the number of treatments and $r$ is the number of replicates. The values of $t_{1}$ and $t_{2}$ were obtained with the Microsoft Office Excel ${ }^{\circledR}$ application, using the functions $t_{1}=I N V T(5 \% ; D F)$ and $t_{2}=I N V T$ (40\%;DF), respectively. Statistical analyses were performed using the Microsoft Office Excel ${ }^{\mathbb{R}}$ application and R software (R Development Core Team, 2020).

\section{RESULTS AND DISCUSSION}

Among the 16 uniformity trials of buckwheat, the average fresh weight $(\mathrm{FW})$ was $1852 \mathrm{~g} \mathrm{~m}^{-2}$ and there was no difference between the cultivars IPR91-Baili (1870 $\left.\mathrm{g} \mathrm{m}^{-2}\right)$ and IPR92-Altar $\left(1833 \mathrm{~g} \mathrm{~m}^{-2}\right)$. At the time of evaluation, i.e., between 45 and 70 days after sowing, the mean dry weight content was $18.39 \%$, and the contents of the cultivars IPR91-Baili (18.99\%) and IPR92-Altar $(17.80 \%)$ did not differ from each other. Consequently, the average dry weight of the cultivars IPR91-Baili (353 $\mathrm{g} \mathrm{m}^{-2}$ ) and IPR92-Altar (324 $\left.\mathrm{g} \mathrm{m}^{-2}\right)$ also did not differ and had an overall mean of $338 \mathrm{~g} \mathrm{~m}^{-2}$ (Table 1). Thus, it can be inferred that the fresh and dry weights were similar between the cultivars IPR91-Baili and IPR92-Altar.

In buckwheat, at 93 days after sowing, that is, at the full flowering stage, Ziech et al. (2015) obtained dry weight of $2.8 \mathrm{Mg} \mathrm{ha}^{-1}$. In cuts performed at 47,57 and 67 days after buckwheat sowing, Görgen et al. (2016) obtained dry weight of 2.301, 3.144 and $4.471 \mathrm{Mg} \mathrm{ha}^{-1}$, respectively. At 71 days after sowing, in the reproductive period between flowering and milky grain stage, Pereira et al. (2017) obtained fresh weight and dry weight of 26.97 and $6.78 \mathrm{Mg} \mathrm{ha}^{-1}$, respectively. Dry weights below $3.00 \mathrm{Mg} \mathrm{ha}^{-1}$ were obtained by Skora Neto and Campos (2017). The different environmental conditions, managements, cultivars and moments of evaluation make comparisons difficult. Nevertheless, it can be noted that the values obtained here were similar to those reported in these studies.

The mean coefficients of variation (CV) of fresh weight among the basic experimental units of $1 \mathrm{~m}^{2}$ were $23.62 \%$ and $25.51 \%$, respectively, for the cultivars IPR91 -Baili and IPR92-Altar, and the difference between the means was not significant (Table 1). No classification ranges of coefficients of variation specific to buckwheat were found in the literature. Thus, taking as reference the classification ranges of the coefficients of variation established by Pimentel-Gomes (2009) for field agricultural trials, these means are within the class of low experimental precision ( $\mathrm{CV}$ between $20 \%$ and 30\%), which demonstrates the need for using a plot size larger than $1 \mathrm{~m}^{2}$ to improve experimental precision. 
Table 1. Sowing and evaluation dates, number of days after sowing (DAS), fresh weight (FW), in $\mathrm{g} \mathrm{m}^{-2}$, coefficient of variation (CV) of fresh weight among the basic experimental units of $1 \mathrm{~m}^{2}$ (CV, in \%), dry weight (DW) content, in \% and dry weight, in $\mathrm{g} \mathrm{m}^{-2}$ of buckwheat, of the cultivars IPR91-Baili and IPR92-Altar, in eight uniformity trials.

\begin{tabular}{|c|c|c|c|c|c|c|c|}
\hline Trial & Sowing & Evaluation & DAS & $\mathrm{FW}$, in $\mathrm{g} \mathrm{m}^{-2}$ & $\mathrm{CV}$, in $\%$ & DW content, in $\%$ & $\mathrm{DW}$, in $\mathrm{g} \mathrm{m}^{-2}$ \\
\hline \multicolumn{8}{|c|}{ IPR91-Baili cultivar ( $\mathrm{n}=8$ uniformity trials) } \\
\hline 1 & $12 / 18 / 2017$ & $02 / 15 / 2018$ & 59 & 3336 & 19.37 & 15.14 & 505 \\
\hline 2 & 01/03/2018 & $03 / 14 / 2018$ & 70 & 3105 & 14.19 & 19.03 & 591 \\
\hline 3 & 03/14/2018 & 05/10/2018 & 57 & 901 & 26.84 & 14.83 & 134 \\
\hline 4 & $11 / 06 / 2018$ & $12 / 27 / 2018$ & 51 & 1227 & 30.53 & 14.42 & 177 \\
\hline 5 & $12 / 28 / 2018$ & $02 / 14 / 2019$ & 48 & 1397 & 17.17 & 18.56 & 259 \\
\hline 6 & 01/30/2019 & $04 / 03 / 2019$ & 63 & 2470 & 23.17 & 20.86 & 515 \\
\hline 7 & $02 / 22 / 2019$ & $04 / 15 / 2019$ & 52 & 2067 & 16.30 & 25.77 & 533 \\
\hline 8 & 03/28/2019 & $05 / 20 / 2019$ & 53 & 459 & 41.40 & 23.30 & 107 \\
\hline Minimum & & & & 459 & 14.19 & 14.42 & 107 \\
\hline Maximum & & & & 3336 & 41.40 & 25.77 & 591 \\
\hline Mean & & & & $1870 \mathrm{a}$ & $23.62 \mathrm{a}$ & $18.99 \mathrm{a}$ & $353 \mathrm{a}$ \\
\hline \multicolumn{8}{|c|}{ IPR92-Altar cultivar ( $\mathrm{n}=8$ uniformity trials) } \\
\hline 1 & $12 / 18 / 2017$ & $02 / 15 / 2018$ & 59 & 3253 & 17.53 & 15.08 & 490 \\
\hline 2 & $01 / 03 / 2018$ & $03 / 14 / 2018$ & 70 & 3311 & 21.26 & 16.82 & 557 \\
\hline 3 & $03 / 14 / 2018$ & $05 / 10 / 2018$ & 57 & 1009 & 23.41 & 17.24 & 174 \\
\hline 4 & $11 / 06 / 2018$ & $12 / 27 / 2018$ & 51 & 1245 & 33.59 & 16.19 & 202 \\
\hline 5 & $12 / 28 / 2018$ & $02 / 14 / 2019$ & 48 & 621 & 32.57 & 15.91 & 99 \\
\hline 6 & 01/30/2019 & 04/03/2019 & 63 & 2635 & 24.81 & 18.31 & 482 \\
\hline 7 & $02 / 22 / 2019$ & $04 / 15 / 2019$ & 52 & 2117 & 20.97 & 23.36 & 494 \\
\hline 8 & 03/28/2019 & 05/20/2019 & 53 & 474 & 29.96 & 19.46 & 92 \\
\hline Minimum & & & & 474 & 17.53 & 15.08 & 92 \\
\hline Maximum & & & & 3311 & 33.59 & 23.36 & 557 \\
\hline Mean & & & & $1833 \mathrm{a}$ & $25.51 \mathrm{a}$ & $17.80 \mathrm{a}$ & $324 \mathrm{a}$ \\
\hline \multicolumn{8}{|c|}{ Overall ( $\mathrm{n}=16$ uniformity trials) } \\
\hline Minimum & & & & 459 & 14.19 & 14.42 & 92 \\
\hline Maximum & & & & 3336 & 41.40 & 25.77 & 591 \\
\hline Mean & & & & 1852 & 24.57 & 18.39 & 338 \\
\hline
\end{tabular}

Means of FW, CV, DW content and DW not followed by the same lowercase letter in the column (comparison of cultivars; $n=8$ uniformity trials) differ by Student's t-test (bilateral), for independent samples, at $5 \%$ probability level.

The wide oscillation of fresh weight $(\mathrm{FW})$ and coefficients of variation between uniformity trials is possibly associated with the different environmental conditions between years and sowing times. This scenario of wide variability lends credibility to the study of plot size determination, as it contemplates real situations that occur in field experiments. The nonsignificant difference between cultivars in relation to $\mathrm{FW}$ and CV suggests that the plot size for experiments with these two buckwheat cultivars may be similar.

In the uniformity trials with the cultivars IPR91Baili (Figure 1) and IPR92-Altar (Figure 2), there was a reduction in variance by BEU between the plots $\left[\mathrm{VU}_{(\mathrm{X})}\right]$, with the increase in the planned plot size $(\mathrm{X})$, which confirms the possibility of improving the experimental precision using plots larger than $1 \mathrm{~m}^{2}$. Visually, there are marked reductions in $\mathrm{VU}_{(\mathrm{X})}$ with plots of up to eight BEU in size $\left(8 \mathrm{~m}^{2}\right)$. After that, the reductions in $\mathrm{VU}_{(\mathrm{X})}$ tend to stabilize, that is, the gains in precision with the increase in plot size become insignificant. In other species, such as velvet bean (CARGNELUTTI FILHO et al., 2014a); forage turnip (CARGNELUTTI FILHO et al., 2014b); and flax (CARGNELUTTI FILHO et al., 2018), the ratio of $\mathrm{VU}_{(\mathrm{X})}$ and $\mathrm{X}$ was similar. Thus, plot of $8 \mathrm{~m}^{2}$ should be used to evaluate the fresh weight of buckwheat. However, the optimal plot size (Xo) should be investigated using appropriate methodologies, such as the method of Hatheway (1961). 

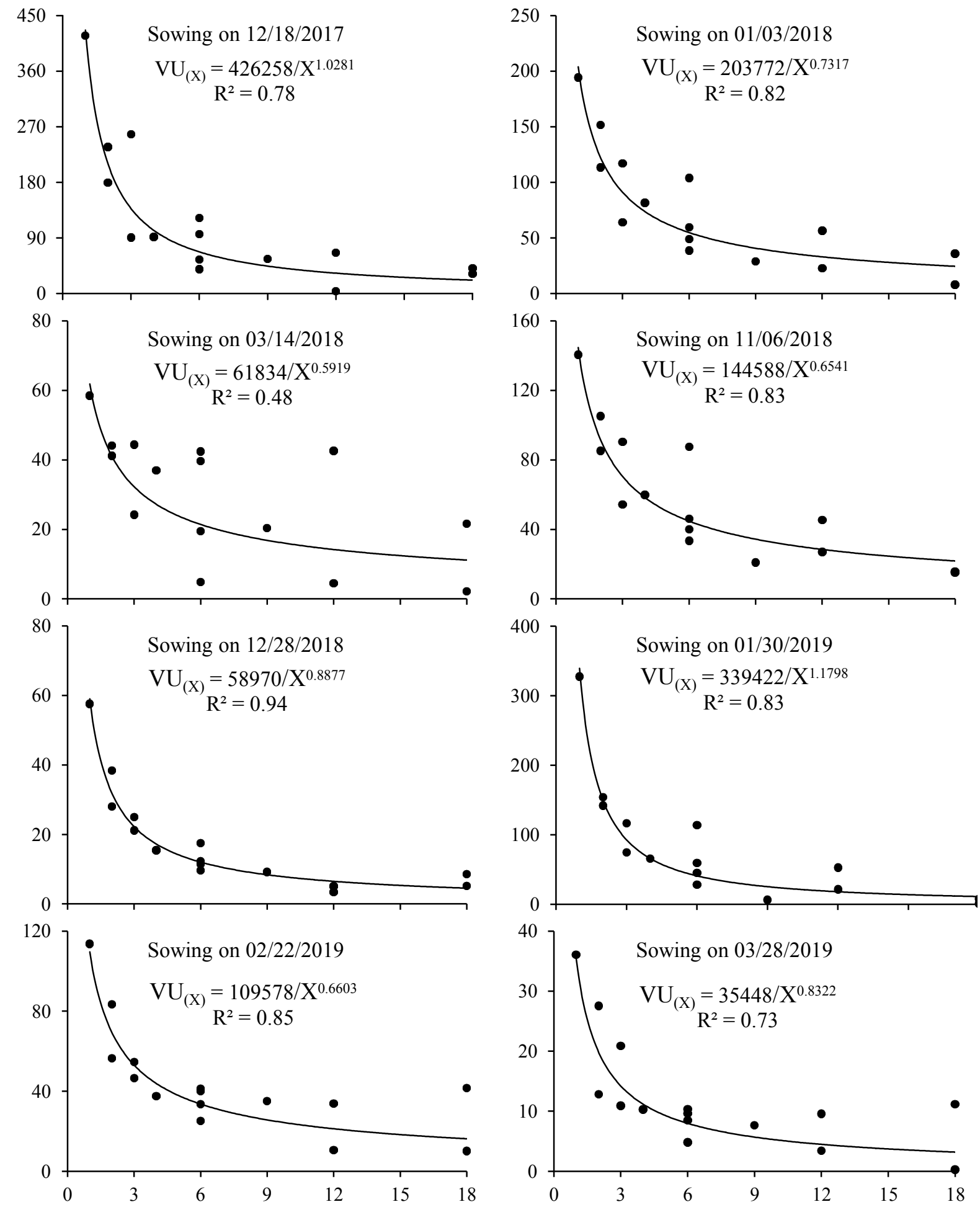

Plot size, in BEU

Figure 1. Graphical representation of the relationship between variance per basic experimental unit (BEU) between the plots with size of $\mathrm{X} \mathrm{BEU}\left[\mathrm{VU}_{(\mathrm{X})}=\mathrm{V}_{(\mathrm{X})} / \mathrm{X}^{2}\right]$, in thousands on the $\mathrm{Y}$ axis, and the planned plot size $(\mathrm{X})$, in BEU on the $\mathrm{X}$ axis, and the estimates of the parameters of the function $\mathrm{VU}(\mathrm{x})=\mathrm{V} 1 / \mathrm{X}^{\mathrm{b}}$ by Smith (1938). Fresh weight data of buckwheat, cultivar IPR91-Baili, obtained in eight uniformity trials. 

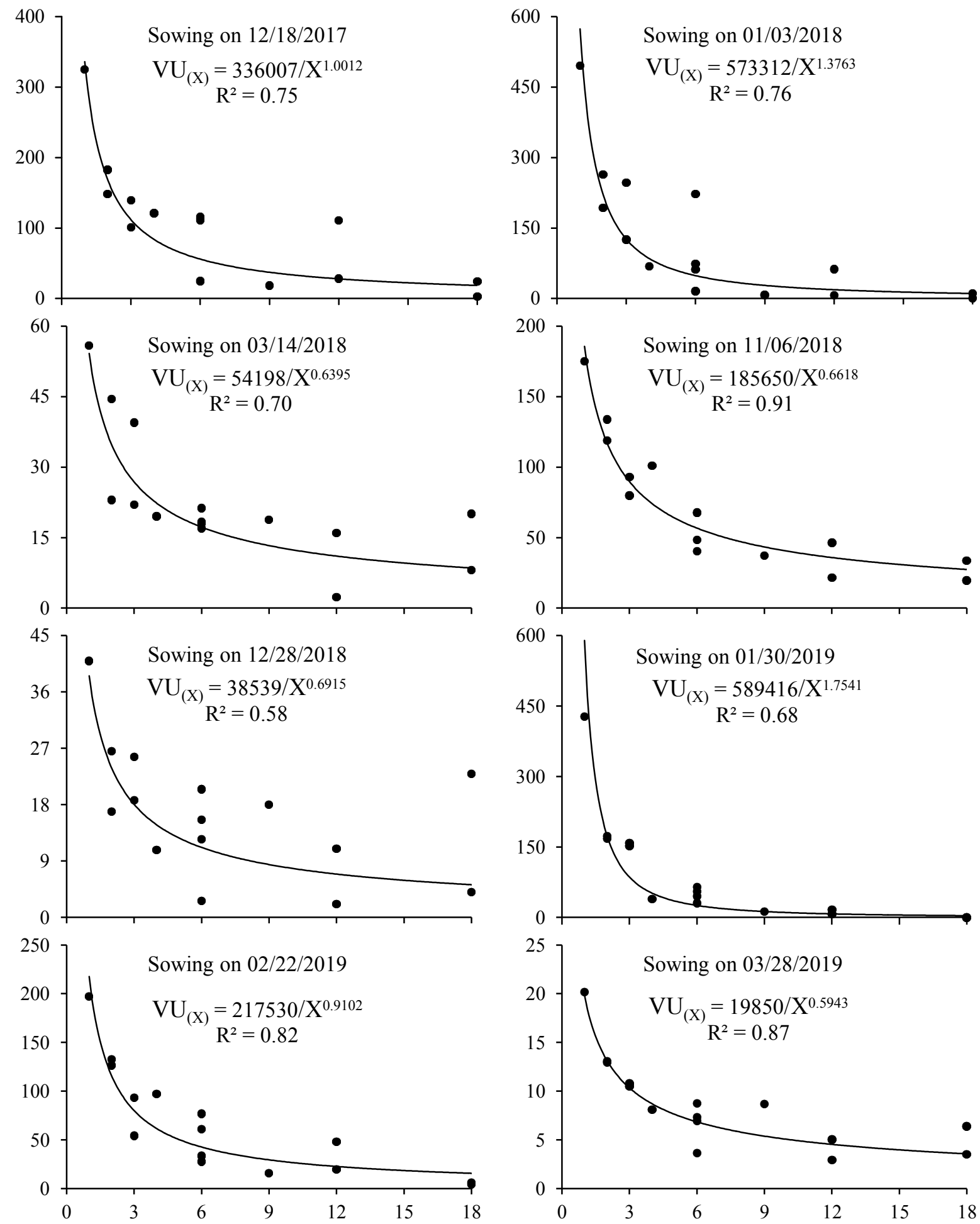

Plot size, in BEU

Figure 2. Graphical representation of the relationship between variance per basic experimental unit (BEU) between the plots with size of $\mathrm{X} \mathrm{BEU}\left[\mathrm{VU}_{(\mathrm{X})}=\mathrm{V}_{(\mathrm{X})} / \mathrm{X}^{2}\right]$, in thousands on the $\mathrm{Y}$ axis, and the planned plot size $(\mathrm{X})$, in BEU on the $\mathrm{X}$ axis, and the estimates of the parameters of the function $\mathrm{VU}(\mathrm{x})=\mathrm{V} 1 / \mathrm{X}^{\mathrm{b}}$ by Smith (1938). Fresh weight data of buckwheat, cultivar IPR92-Altar, obtained in eight uniformity trial.

To evaluate the fresh weight of the buckwheat cultivars IPR91-Baili and IPR92-Altar, in experiments conducted in the completely randomized design (CRD) and randomized complete block design (RCBD), the optimal plot size (Xo), estimated by the method of Hatheway (1961), from a fixed number of treatments (i) and replicates (r), increases with the increase of precision (d) (Table 2). For example, to evaluate $\mathrm{FW}$ in an 
experiment with the cultivar IPR91-Baili, conducted in the CRD with five treatments $(\mathrm{i}=5)$ and eight replicates $(\mathrm{r}=8)$, aiming that in $80 \%$ of the experiments (power $=0.80$ ) differences between treatments of $d=20 \%$ of the overall mean of the experiment (lower precision) are detected as significant at 5\% probability level, the plot size should be $4 \mathrm{BEU}\left(4 \mathrm{~m}^{2}\right)$. Plot sizes equal to or larger than this are feasible in field experiments, which makes it possible to improve experimental precision. For example, plots of $8 \mathrm{~m}^{2}$, as suggested in this study, would make it possible to obtain $\mathrm{d}=15 \%$. Under these same conditions, for $\mathrm{d}=10 \%$ (higher precision), a plot with 20 BEU $\left(20 \mathrm{~m}^{2}\right)$ would necessary. High experimental precisions (low percentages of d) are difficult to achieve in practice, due to the need for large plot size. Similar results were observed for the cultivar IPR92-Altar.

Table 2. Optimal plot size, in $\mathrm{m}^{2}$, for the completely randomized design (CRD) and randomized complete block design (RCBD), in combinations of $i$ treatments, $r$ replicates and d precision levels, for the fresh weight of buckwheat, of cultivars IPR91-Baili and IPR92Altar.

\begin{tabular}{|c|c|c|c|c|c|c|c|c|c|c|c|c|c|c|c|c|c|c|c|c|c|c|c|c|}
\hline \multirow[t]{2}{*}{$\mathrm{d}(\%)$} & \multicolumn{6}{|c|}{$\mathrm{i}=5$ treatments } & \multicolumn{6}{|c|}{$\mathrm{i}=10$ treatments } & \multicolumn{6}{|c|}{$\mathrm{i}=15$ treatments } & \multicolumn{6}{|c|}{$\mathrm{i}=20$ treatments } \\
\hline & $\mathrm{r}=3$ & $\mathrm{r}=4$ & $\mathrm{r}=5$ & $\mathrm{r}=6$ & $\mathrm{r}=7$ & $\bar{r}=8$ & $\mathrm{r}=3$ & $\mathrm{r}=4$ & $\mathrm{r}=5$ & $\mathrm{r}=6$ & $\mathrm{r}=7$ & $\mathrm{r}=8$ & $\mathrm{r}=3$ & $\mathrm{r}=4$ & $\mathrm{r}=5$ & $\mathrm{r}=6$ & $\mathrm{r}=7$ & $\mathrm{r}=8$ & $\mathrm{r}=3$ & $\mathrm{r}=4$ & $\mathrm{r}=5$ & $\mathrm{r}=6$ & $\mathrm{r}=7$ & $\mathrm{r}=8$ \\
\hline & \multicolumn{24}{|c|}{ CRD - IPR91-Baili $(\mathrm{b}=0.8207 ; \mathrm{CV}=23.62 \%)$} \\
\hline 10 & 79 & 51 & 38 & 29 & 24 & 20 & 69 & 47 & 35 & 28 & 23 & 20 & 67 & 46 & 35 & 28 & 23 & 19 & 65 & 45 & 34 & 27 & 23 & 19 \\
\hline 11 & 63 & 41 & 30 & 23 & 19 & 16 & 55 & 37 & 28 & 22 & 18 & 16 & 53 & 36 & 28 & 22 & 18 & 15 & 52 & 36 & 27 & 22 & 18 & 15 \\
\hline 12 & 51 & 33 & 24 & 19 & 16 & 13 & 45 & 30 & 23 & 18 & 15 & 13 & 43 & 30 & 22 & 18 & 15 & 13 & 42 & 29 & 22 & 18 & 15 & 13 \\
\hline 13 & 42 & 27 & 20 & 16 & 13 & 11 & 37 & 25 & 19 & 15 & 12 & 11 & 35 & 24 & 18 & 15 & 12 & 10 & 35 & 24 & 18 & 15 & 12 & 10 \\
\hline 14 & 35 & 23 & 17 & 13 & 11 & 9 & 31 & 21 & 16 & 13 & 10 & 9 & 30 & 20 & 16 & 12 & 10 & & 29 & 20 & 15 & 12 & 10 & 9 \\
\hline 15 & 0 & 19 & 14 & 1 & 9 & 8 & 6 & 18 & 13 & 11 & 9 & 8 & 25 & 17 & 13 & 11 & 0 & & 25 & 17 & 13 & 10 & 9 & 7 \\
\hline 16 & 25 & 17 & 12 & 10 & 8 & 7 & 22 & 15 & 12 & 9 & 8 & 7 & 22 & 15 & 11 & 0 & 8 & & 21 & 15 & 11 & 9 & 8 & 6 \\
\hline 17 & 22 & 14 & 11 & 8 & 7 & 6 & 19 & 13 & 10 & 8 & 7 & 6 & 19 & 13 & 10 & 8 & 7 & & 18 & 13 & 10 & 8 & 7 & 6 \\
\hline 18 & 19 & 13 & 9 & 7 & 6 & 5 & 17 & 12 & 9 & 7 & 6 & 5 & 16 & 11 & 9 & 7 & 6 & & 16 & 11 & 9 & 7 & 6 & 5 \\
\hline 19 & 17 & 11 & 8 & 7 & 5 & 5 & 15 & 10 & 8 & 6 & 5 & 4 & 14 & 10 & 8 & 6 & 5 & & 14 & 10 & 8 & 6 & 5 & 4 \\
\hline \multirow[t]{2}{*}{20} & 15 & 10 & 7 & 6 & 5 & 4 & 13 & 9 & 7 & 6 & 5 & 4 & 13 & 9 & 7 & 5 & 5 & 4 & 12 & 9 & 7 & 5 & 5 & 4 \\
\hline & \multicolumn{24}{|c|}{ RCBD - IPR91-Baili $(b=0.8207 ; \mathrm{CV}=23.62 \%)$} \\
\hline$\overline{10}$ & 85 & 53 & 39 & 30 & 25 & 21 & 70 & 48 & 36 & 28 & 23 & 20 & 67 & 46 & 35 & 28 & 23 & 19 & 66 & 45 & 34 & 27 & 23 & 19 \\
\hline 11 & 67 & 42 & 31 & 24 & 20 & 16 & 56 & 38 & 28 & 22 & 19 & 16 & 53 & 37 & 28 & 22 & 18 & 15 & 52 & 36 & 27 & 22 & 18 & 15 \\
\hline 12 & 54 & 34 & 25 & 20 & 16 & 13 & 45 & 31 & 23 & 18 & 15 & 13 & 43 & 30 & 22 & 18 & 15 & 13 & 42 & 29 & 22 & 18 & 15 & 13 \\
\hline 13 & 45 & 28 & 21 & 16 & 13 & 11 & 37 & 25 & 19 & 15 & 12 & 11 & 36 & 25 & 19 & 15 & 12 & 10 & 35 & 24 & 18 & 15 & 12 & 10 \\
\hline 14 & 38 & 24 & 17 & 14 & 11 & 9 & 31 & 21 & 16 & 13 & 11 & 9 & 30 & 21 & 16 & 12 & 10 & 0 & 29 & 20 & 15 & 12 & 10 & 9 \\
\hline 15 & 32 & 20 & 15 & 12 & 9 & 8 & 27 & 18 & 14 & 11 & 9 & 0 & 25 & 17 & 13 & 11 & 9 & $\varepsilon$ & 25 & 17 & 13 & 11 & 9 & 7 \\
\hline 16 & 27 & 17 & 13 & 10 & 8 & 7 & 23 & 15 & 12 & 9 & 8 & 7 & 22 & 15 & 11 & 9 & 8 & 7 & 21 & 15 & 11 & 9 & 8 & 6 \\
\hline 17 & 24 & 15 & 11 & 9 & 7 & 6 & 20 & 13 & 10 & 8 & 7 & 6 & 19 & 13 & 10 & 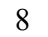 & 7 & 6 & 18 & 13 & 10 & 8 & 7 & 6 \\
\hline 18 & 21 & 13 & 10 & 8 & 6 & 5 & 17 & 12 & 9 & 7 & 6 & 5 & 16 & 11 & 9 & 7 & 6 & 5 & 16 & 11 & 9 & 7 & 6 & 5 \\
\hline 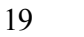 & 18 & 12 & 8 & 7 & 6 & 5 & 15 & 10 & 8 & 6 & 5 & 5 & 14 & 10 & 8 & 6 & 5 & 4 & 14 & 10 & 8 & 6 & 5 & 4 \\
\hline 20 & 16 & 10 & 8 & 6 & 5 & 4 & 13 & 9 & 7 & 6 & 5 & 4 & 13 & 9 & 7 & 6 & 5 & 4 & 13 & 9 & 7 & 5 & 5 & 4 \\
\hline
\end{tabular}

CRD - IPR92-Altar $(\mathrm{b}=0.9536 ; \mathrm{CV}=25.51 \%)$

\begin{tabular}{ccccccccccccccccccccccccccccc}
\hline 10 & 51 & 35 & 27 & 22 & 18 & 16 & 45 & 33 & 25 & 21 & 18 & 15 & 44 & 32 & 25 & 21 & 18 & 15 & 43 & 31 & 25 & 20 & 17 & 15 \\
11 & 42 & 29 & 22 & 18 & 15 & 13 & 37 & 27 & 21 & 17 & 15 & 13 & 36 & 26 & 21 & 17 & 14 & 13 & 35 & 26 & 20 & 17 & 14 & 13 \\
12 & 35 & 24 & 18 & 15 & 13 & 11 & 31 & 22 & 18 & 14 & 12 & 11 & 30 & 22 & 17 & 14 & 12 & 11 & 30 & 22 & 17 & 14 & 12 & 11 \\
13 & 29 & 20 & 16 & 13 & 11 & 9 & 26 & 19 & 15 & 12 & 10 & 9 & 25 & 19 & 15 & 12 & 10 & 9 & 25 & 18 & 15 & 12 & 10 & 9 \\
14 & 25 & 18 & 13 & 11 & 9 & 8 & 23 & 16 & 13 & 11 & 9 & 8 & 22 & 16 & 13 & 10 & 9 & 8 & 22 & 16 & 12 & 10 & 9 & 8 \\
15 & 22 & 15 & 12 & 10 & 8 & 7 & 20 & 14 & 11 & 9 & 8 & 7 & 19 & 14 & 11 & 9 & 8 & 7 & 19 & 14 & 11 & 9 & 8 & 7 \\
16 & 19 & 13 & 10 & 8 & 7 & 6 & 17 & 12 & 10 & 8 & 7 & 6 & 17 & 12 & 10 & 8 & 7 & 6 & 16 & 12 & 10 & 8 & 7 & 6 \\
17 & 17 & 12 & 9 & 7 & 6 & 6 & 15 & 11 & 9 & 7 & 6 & 5 & 15 & 11 & 9 & 7 & 6 & 5 & 14 & 11 & 8 & 7 & 6 & 5 \\
18 & 15 & 11 & 8 & 7 & 6 & 5 & 14 & 10 & 8 & 6 & 6 & 5 & 13 & 10 & 8 & 6 & 5 & 5 & 13 & 10 & 8 & 6 & 5 & 5 \\
19 & 14 & 9 & 7 & 6 & 5 & 4 & 12 & 9 & 7 & 6 & 5 & 4 & 12 & 9 & 7 & 6 & 5 & 4 & 12 & 9 & 7 & 6 & 5 & 4 \\
20 & 12 & 9 & 7 & 5 & 5 & 4 & 11 & 8 & 6 & 5 & 5 & 4 & 11 & 8 & 6 & 5 & 4 & 4 & 10 & 8 & 6 & 5 & 4 & 4 \\
\hline
\end{tabular}

\begin{tabular}{cccccccccccccccccccccccccc}
\hline & \multicolumn{11}{c|}{ RCBD - IPR92-Altar $(\mathrm{b}=0.9536 ; \mathrm{CV}=25.51 \%)$} \\
\hline 10 & 54 & 36 & 28 & 22 & 19 & 16 & 46 & 33 & 26 & 21 & 18 & 15 & 44 & 32 & 25 & 21 & 18 & 15 & 43 & 32 & 25 & 20 & 17 & 15 \\
11 & 44 & 30 & 23 & 18 & 15 & 13 & 38 & 27 & 21 & 17 & 15 & 13 & 36 & 26 & 21 & 17 & 14 & 13 & 35 & 26 & 20 & 17 & 14 & 13 \\
12 & 37 & 25 & 19 & 15 & 13 & 11 & 32 & 23 & 18 & 14 & 12 & 11 & 30 & 22 & 17 & 14 & 12 & 11 & 30 & 22 & 17 & 14 & 12 & 11 \\
13 & 31 & 21 & 16 & 13 & 11 & 9 & 27 & 19 & 15 & 12 & 10 & 9 & 26 & 19 & 15 & 12 & 10 & 9 & 25 & 18 & 15 & 12 & 10 & 9 \\
14 & 27 & 18 & 14 & 11 & 9 & 8 & 23 & 16 & 13 & 11 & 9 & 8 & 22 & 16 & 13 & 10 & 9 & 8 & 22 & 16 & 13 & 10 & 9 & 8 \\
15 & 23 & 16 & 12 & 10 & 8 & 7 & 20 & 14 & 11 & 9 & 8 & 7 & 19 & 14 & 11 & 9 & 8 & 7 & 19 & 14 & 11 & 9 & 8 & 7 \\
16 & 20 & 14 & 11 & 9 & 7 & 6 & 17 & 13 & 10 & 8 & 7 & 6 & 17 & 12 & 10 & 8 & 7 & 6 & 16 & 12 & 10 & 8 & 7 & 6 \\
17 & 18 & 12 & 9 & 8 & 6 & 6 & 15 & 11 & 9 & 7 & 6 & 5 & 15 & 11 & 9 & 7 & 6 & 5 & 15 & 11 & 8 & 7 & 6 & 5 \\
18 & 16 & 11 & 8 & 7 & 6 & 5 & 14 & 10 & 8 & 6 & 6 & 5 & 13 & 10 & 8 & 6 & 5 & 5 & 13 & 10 & 8 & 6 & 5 & 5 \\
19 & 14 & 10 & 8 & 6 & 5 & 5 & 12 & 9 & 7 & 6 & 5 & 4 & 12 & 9 & 7 & 6 & 5 & 4 & 12 & 9 & 7 & 6 & 5 & 4 \\
20 & 13 & 9 & 7 & 6 & 5 & 4 & 11 & 8 & 6 & 5 & 5 & 4 & 11 & 8 & 6 & 5 & 4 & 4 & 10 & 8 & 6 & 5 & 4 & 4 \\
\hline
\end{tabular}


For the cultivars IPR91-Baili and IPR92-Altar, in the CRD and RCBD designs, with fixed values of $i$ and $\mathrm{d}$, the Xo decreases with the increment in r. Also, with fixed values of $r$ and $d$, there is a reduction in Xo with the increment in $\mathrm{i}$ (Table 2). In an analysis of variance, the greater the number of treatments and the number of replicates, the greater the number of degrees of freedom of the error and, consequently, the lower the mean square of the error (residual variance), that is, the higher the experimental precision. However, in this context, Sousa et al. (2015) concluded that the increase in the number of replicates and plot size were more efficient to increase experimental precision than the increase in the number of cultivars (treatments).

In the methodology of Hatheway (1961), based on the fixed value of the soil heterogeneity index (b) of Smith (1938) and CV, the Xo is dependent on i, r and d. Thus, based on the number of treatments and the desired precision, it is possible to use the information of this study to define the plot size and the number of replicates. For example, if the researcher wants to evaluate the FW of five treatments of buckwheat, IPR91-Baili cultivar, in the $\mathrm{CRD}$, and wants precision (d) of $10 \%$, among the various options, he/she can use plots of $79 \mathrm{BEU}\left(79 \mathrm{~m}^{2}\right)$ and three replicates, $51 \mathrm{BEU}\left(51 \mathrm{~m}^{2}\right)$ and four replicates, $38 \mathrm{BEU}\left(38 \mathrm{~m}^{2}\right)$ and five replicates, $29 \mathrm{BEU}\left(29 \mathrm{~m}^{2}\right)$ and six replicates, $24 \mathrm{BEU}\left(24 \mathrm{~m}^{2}\right)$ and seven replicates or 20 BEU $\left(20 \mathrm{~m}^{2}\right)$ and eight replicates (Table 2). In these six options, the area of the experiment would be, respectively, $1185,1020,950,870,840$, and $800 \mathrm{~m}^{2}$.

Therefore, for the same precision $(\mathrm{d}=10 \%$, in this case), smaller plots and a greater number of replicates are more efficient in the use of the experimental area, as discussed in Cargnelutti Filho et al. (2014a, b), Storck et al. (2016) and Cargnelutti Filho et al. (2018). It is important to consider that the increase in the number of replicates requires a greater number of evaluations and, if the trait is difficult to be measured and/or costly to be evaluated, the use of larger plot size and smaller number of replicates can be advantageous, as long as there is sufficient experimental area. In addition, smaller plot sizes may not represent plant development, while larger plots would make it possible to evaluate the plants in the central area (useful area) and disregard the borders, reducing the interference from plants of the adjacent plots, that is, the inter-plot competition (STORCK et al., 2016). Therefore, the researcher should investigate within its availability of experimental area, number of treatments to be evaluated and the desired precision, which combination of plot size and number of replicates is most appropriate.

The information in this study allows investigations in 264 scenarios formed by combinations of $i$ treatments $(i=5,10,15$, and 20$)$, r replicates $(r=3$, $4,5,6,7$, and 8) and d differences between means of treatments to be detected as significant at 5\% probability level $(\mathrm{d}=10 \%, 11 \%, 12 \%, 13 \%, 14 \%, 15 \%, 16 \%, 17 \%$, $18 \%, 19 \%$, and $20 \%$ ), for each cultivar and each design (Table 2). Other scenarios can be simulated by means of the expression $X o=\sqrt[b]{2\left(t_{1}+t_{2}\right)^{2} C V^{2} / r d^{2}}$ (HATHEWAY, 1961), based on the mean soil heterogeneity index (b) of the function of Smith (1938) and on the mean coefficient of variation $(\mathrm{CV})$ of the $\mathrm{FW}$, from the eight trials of each cultivar. In this context, as an example, to evaluate the $\mathrm{FW}$ of eight treatments of buckwheat, IPR91-Baili cultivar, with four replicates and with $\mathrm{d}=10 \%$, in the $\mathrm{RCBD}$, the parameters are: $\mathrm{b}=0.8207 ; \quad \mathrm{DF}=(8-1)(4-1)=21 ; \quad \mathrm{t}_{1}=\operatorname{INVT}(5 \% ; 21)$ $=2.07961383 ; \quad \mathrm{t}_{2}=\mathrm{INVT}(40 \% ; 21)=0.85907403$; $\mathrm{CV}=23.62 \% ; \quad \mathrm{r}=4 ; \quad \mathrm{d}=10 \%$. Therefore, the optimal plot size (Xo) will be: $X_{0}=\sqrt[0.8207]{2(2.07961383+0.85907403)^{2} 23.62^{2} / 4 \times 10^{2}}=48.28 \cong 49 \mathrm{BEU}$.

The Xo of 49 BEU was assumed because, according to the criterion established in this study, the Xo is approximated to the immediately higher integer. For the simulation of scenarios in the completely randomized design (CRD), only the expression to calculate the number of degrees of freedom is changed, that is, for this design, $\mathrm{DF}=\mathrm{i}(\mathrm{r}-1)$, where $\mathrm{i}$ is the number of treatments and $r$ is the number of replicates. Thus, for this example the parameters are: $b=0.8207 ; \mathrm{DF}=(8)(4-1)=24 ; \mathrm{t}_{1}=\mathrm{INVT}$ $(5 \% ; 24)=2.06389854 ; \quad t_{2}=\operatorname{INVT}(40 \% ; 24)=0.85685545$; $\mathrm{CV}=23.62 \% ; \quad \mathrm{r}=4 ; \quad \mathrm{d}=10 \% . \quad$ Therefore, $X_{0}=\sqrt[0.8207]{2(2.06389854+0.85685545)^{2} 23.62^{2} / 4 \times 10^{2}}=47.56 \cong 48 \mathrm{BEU}$.

For the same experimental dimensions, the smaller plot size in the CRD (48 BEU) in comparison to the RCBD (49 BEU) confirms the higher efficiency of the CRD when the experimental area is homogeneous (STORCK et al., 2016).

The results of this study serve to define the plot size and the number of replicates in experiments to evaluate the fresh weight of the buckwheat cultivars IPR91-Baili and IPR92-Altar, in experiments conducted in the completely randomized design (CRD) and randomized complete block design (RCBD). It is indicated, as reference, for the planning of experiments with buckwheat, the use of plots of $8 \mathrm{~m}^{2}$. This indication is supported by the practical viability in the field and stabilization of precision from this size. This plot size is slightly larger than that used by Pereira et al. (2017) and smaller than those used by Ziech et al. (2015), Görgen et al. (2016) and Skora Neto and Campos (2017) in studies with buckwheat along with other soil cover species.

\section{CONCLUSIONS}

In experiments to evaluate the fresh weight of the buckwheat cultivars IPR91-Baili and IPR92-Altar, in the completely randomized design and randomized complete block design, with 5 to 20 treatments and with eight replicates, plots with useful area of $8 \mathrm{~m}^{2}$ are sufficient to identify significant differences between treatments, at $5 \%$ probability level, of $15 \%$ of the overall mean of the experiment. 


\section{ACKNOWLEDGMENTS}

To the National Council for Scientific and Technological Development $(\mathrm{CNPq}-$ Processes 401045/2016-1 and 304652/2017-2), the Coordination for the Improvement of Higher Education Personnel (CAPES), and the Rio Grande do Sul Research Support Foundation (FAPERGS) for granting scholarships to the authors. To scholarship students and volunteers for their assistance in data collection

\section{REFERENCES}

ACCAME, M. E. C.; ORTEGA, T. Trigo sarraceno. Panorama Actual del Medicamento, 43: 133-136, 2019.

ALVARES, C. A. et al. Köppen's climate classification map for Brazil. Meteorologische Zeitschrift, 22: 711$728,2013$.

CARGNELUTTI FILHO, A. et al. Planejamentos experimentais em nabo forrageiro semeado a lanço e em linha. Bioscience Journal, 30: 677-686, 2014b.

CARGNELUTTI FILHO, A. et al. Plot size related to numbers of treatments, repetitions, and the experimental precision in flax. Comunicata Scientiae, 9: 629-636, 2018.

CARGNELUTTI FILHO, A. et al. Tamanho de parcela para avaliar a massa de plantas de mucuna cinza. Comunicata Scientiae, 5: 196-204, 2014a.

DONATO, S. L. R. et al. Experimental planning for the evaluation of phenotipic descriptors in banana. Revista Brasileira de Fruticultura, 40: 1-13, 2018.

GONÇALVES, F. M. F. et al. Fagopyrum esculentum Moench: A crop with many purposes in agriculture and human nutrition. African Journal of Agricultural Research, 11: 983-989, 2016.

GÖRGEN, A. V. et al. Produtividade e qualidade da forragem de trigo-mourisco (Fagopyrum esculentum Moench) e de milheto (Pennisetum glaucum (L.) R.BR).

Revista Brasileira de Saúde e Produção Animal, 17: 599-607, 2016.

GUIMARÃES, B. V. C. et al. Methods for estimating optimum plot size for 'Gigante' cactus pear. Journal of Agricultural Science, 11: 205-211, 2019.

GUIMARÃES, B. V. C. et al. Optimal plot size for experimental trials with Opuntia cactus pear. Acta Scientiarum. Technology, 42: e42579, 2020.

HATHEWAY, W. H. Convenient plot size. Agronomy
Journal, 53: 279-280, 1961.

MAYOR-DURÁN, V. M.; BLAIR, M.; MUÑOZ, J. E. Metodología para estimar el coeficiente de heterogeneidad del suelo, el número de repeticiones y el tamaño de parcela en investigaciones con frijol (Phaseolus vulgaris L.). Acta Agronomica, 61: 32-39, 2012.

MIKHAILOVICH, G. N. Las bases para cultivo de alforfón (trigo sarraceno) Fagopyrum esculentum en centroamérica. Revista Científica Tecnológica, 2: 8-13, 2019.

PEREIRA, A. P. et al. C. Ciclagem de nutrientes por plantas de cobertura de verão. Revista de Ciências Agrárias, 40: 799-807, 2017.

PIMENTEL-GOMES, F. Curso de estatística experimental. 15. ed. Piracicaba, SP: FEALQ, 2009. $451 \mathrm{p}$.

R Development Core Team R: A Language and Environment for Statistical Computing. Vienna: R Foundation for Statistical Computing. 2020.

SANTOS, H. G. et al. Sistema Brasileiro de Classificação de Solos. 5. ed. revisada e ampliada. Brasília, DF: Embrapa, 2018. 356 p. Disponível em: $<$ https://www.infoteca.cnptia.embrapa.br/handle/ doc/1094003>. Acesso em: 23 mar. 2020.

SKORA NETO, F.; CAMPOS, A. C. Plantas de cobertura antecedendo a cultura de trigo. Scientia Agraria Paranaensis, 16: 463-467, 2017.

SMITH, H. F. An empirical law describing heterogeneity in the yields of agricultural crops. Journal of Agricultural Science, 28: 1-23, 1938.

SOUSA, R. P. et al. Optimum plot size for experiments with the sunflower. Revista Ciência Agronômica, 46: 170-175, 2015.

SOUSA, R. P.; SILVA, P. S. L.; ASSIS, J. P. Tamanho e forma de parcelas para experimentos com girassol. Revista Ciência Agronômica, 47: 683-690, 2016.

STORCK, L. et al. Experimentação vegetal. 3. ed. Santa Maria, RS: UFSM, 2016. 198 p.

YILMAZ, H. Ö.; AYHAN, N. Y.; MERIÇ, Ç. S. Buckwheat: A Useful Food and its Effects on Human Health. Current Nutrition \& Food Science, 16: 29-34, 2020 .

ZIECH, A. R. D. et al. Proteção do solo por plantas de cobertura de ciclo hibernal na região Sul do Brasil. Pesquisa Agropecuária Brasileira, 50: 374-382, 2015. 